\title{
Social wasps (Vespinae) in urban gardens and woods
}

\author{
Atte Komonen*, Aleksi Nirhamo \& Jyrki Torniainen
}

\begin{abstract}
Department of Biological and Environmental Science, School of Resource Wisdom, P.O. Box 35, Fl-40014 University of Jyväskylä, Finland ( ${ }^{*}$ corresponding author's e-mail: atte.komonen@jyu.fi)
\end{abstract}

Received 8 Jan. 2020, final version received 16 Jan. 2020, accepted 16 Jan. 2020

Komonen, A., Nirhamo, A. \& Torniainen J. 2020: Social wasps (Vespinae) in urban gardens and woods. - Ann. Zool. Fennici 57: 41-46.

Global change, including urbanization, affects species ecology. Social wasps (Vespinae) are ubiquitous in urban areas, which increases their encounters with humans. We studied social wasps in urban gardens and nearby urban woods in central Finland, using beer traps. Social wasps were common in gardens and woods, and overall wasp abundance was higher in the woods. Also, the most abundant and frequent species Vespula vulgaris was more abundant in the woods than in the gardens. Variation in the overall abundance and the abundance of $V$. vulgaris was great among trap locations, which likely results from wasps' social nesting habits. Neither the abundance of all social wasps nor that of $V$. vulgaris differed between July and August. Our study suggests that urban woods might increase wasp abundance in adjacent gardens. Vespula germanica - a species expanding its range northwards in Finland - was documented for the first time from central Finland. The ongoing global change is likely to change wasp communities and their encounters with humans in urban environments.

\section{Introduction}

Urbanization is an extreme and increasing anthropogenic pressure on natural biota. It destroys and fragments natural habitats and is a leading cause of species declines (McKinney 2002, McDonald et al. 2013). At the same time, however, urbanization creates novel biotopes: parks, gardens, wasteland, road verges, dump pits and buildings, which provide shelter, nest sites and food for many species (Niemelä 1999). Environmental conditions, such as temperature, in urban areas also differ from those in natural habitats (Grimmond 2007). Although arthropod predators and parasitoids, such as wasps, are among the first groups to disappear from fragmented landscapes (Kruess \& Tscharntke 1994), social wasps (Vespinae) are often ubiquitous in urban areas. Sometimes they can be experienced as a nuisance (Sumner et al. 2018), since wasp sting is painful and even life threatening for allergic persons.

Many factors affect social wasp distribution and abundance across urbanization gradient. Social wasp are generalist predators. They collect protein food (mainly invertebrates) for larvae and carbohydrate food (e.g. nectar and sap) for their own nutrition (Raveret Richter 2000). Additional protein they obtain from carcasses and meat leftovers discarded by humans in gardens and camping sites. Similarly, humans provide additional carbohydrate sources, such as fruits and berries in gardens, and half-empty soft drinks and other sugary leftovers. Foraging distances vary depending on species, location and availability of food sources, but in most cases 
they are some hundreds of meters around the nest (Archer 2012). Considering human-wasp encounters, this means that gardens and other urban areas interact with surrounding seminatural biotopes, such as forests and grasslands.

Urbanization can promote colony development in comparison with more natural vegetation, although such response is species specific (Christie \& Hochuli 2009, Nadolski 2013, Sorvari 2018). For example, Vespula vulgaris is often more abundant outside urban areas, whereas $V$. germanica is often more abundant in urban areas (Sorvari 2018). In urban areas, colony size can also become larger than in native vegetation (Jeanne \& Bouwma 2002, Nadolski 2012), due to favourable microclimate, abundant food and spacious nesting sites in buildings (Nadolski 2012). Given the increase in colony size during summer, wasp abundance in south-central Finland reaches its peak in late July to late August, depending on the species and year (Pekkarinen \& Huldén 1995); especially those species, which are readily beertrapped (Sorvari 2013), typically peak in August. To our knowledge, however, no studies have compared the species composition and abundance of social wasps in urban gardens and nearby woods. Such knowledge is important to better understand the ecological basis of human-wasp encounters and coexistence dynamics.

Our goal was to study the ecology of humanwasp encounters in an urban environment. We asked whether there was a difference in the social wasp abundance between gardens of private houses and nearby urban woods, as well as between July and August. We hypothesized that the wasp abundance would differ between gardens and woods, as well as between July and August, but the response would be species specific.

\section{Material and methods}

The study was conducted in small backyard gardens of private houses in the city of Jyväskylä (population ca. 100 000) in central Finland. Potential gardens were identified via an email query to the faculty and staff members of the Jyväskylä University. From the volunteered households, we chose gardens $(n=22)$ which were spread rather evenly within $10 \mathrm{~km}$ of the city centre. For each garden, we selected the nearest wood $(n=22)$ and placed the trap 50 to $200 \mathrm{~m}$ from the nearest building. Some woods were part of the more continuous forests surrounding the city, but some were isolated pockets in the midst of buildings. The sites were located within roughly $18 \mathrm{~km}^{2}$.

Traps were hung in trees or bushes 1.5 to $2 \mathrm{~m}$ above ground and were not directly exposed to sun. At each site, we placed one bait trap, filled with $2 \mathrm{dl}$ of beer and a hint of brown sugar and dry yeast (see Sorvari 2013). The traps were set for two 12-day periods: 15-26 July 2019 and 12-23 August 2019. The mean maximum daily temperature was higher in July $\left(25^{\circ} \mathrm{C}\right)$ than in August $\left(20^{\circ} \mathrm{C}\right.$ ) (Finnish Meteorological Institute 2020; measured at Tikkakoski $17 \mathrm{~km}$ north of Jyväskylä). The cumulative precipitation was lower in July $(0.9 \mathrm{~mm})$ than in August $(41 \mathrm{~mm})$.

The second period overlapped with the peak of the wasp abundance in Jyväskylä (Fig. 1). In both periods, the traps were exactly in the same locations. All individuals were identified to species, sex and caste (queens, worker, males) following Douwes et al. (2012). Differences in the numbers of individuals between gardens and woods in the two sampling periods were analysed with generalized linear mixed models, as implemented in IBM SPSS Statistics ver. 24. The data structure was such that the trap identity was considered a subject and the sampling period a repeated measure. Because the data were counts of individuals, Poisson distribution with a log link was used. Habitat and sampling period were included as fixed main effects, and their interaction was included to test whether the effect of sampling period is similar in both habitats. For post-estimation settings, degrees of freedom were estimated using the residual method, and the tests of fixed effects and coefficients were estimated using model-based covariances. Differences in variance were analysed with an $F$-test. In August, one trap in the woods was damaged and filled with water, so we removed this trap from the analyses.

\section{Results}

In total, we recorded 7 species and 388 individuals (Table 1). In the July sampling period, we 
Fig. 1. Weekly numbers of wasps in the city of Jyväskylä in 2019, based on two sets of three beer traps.

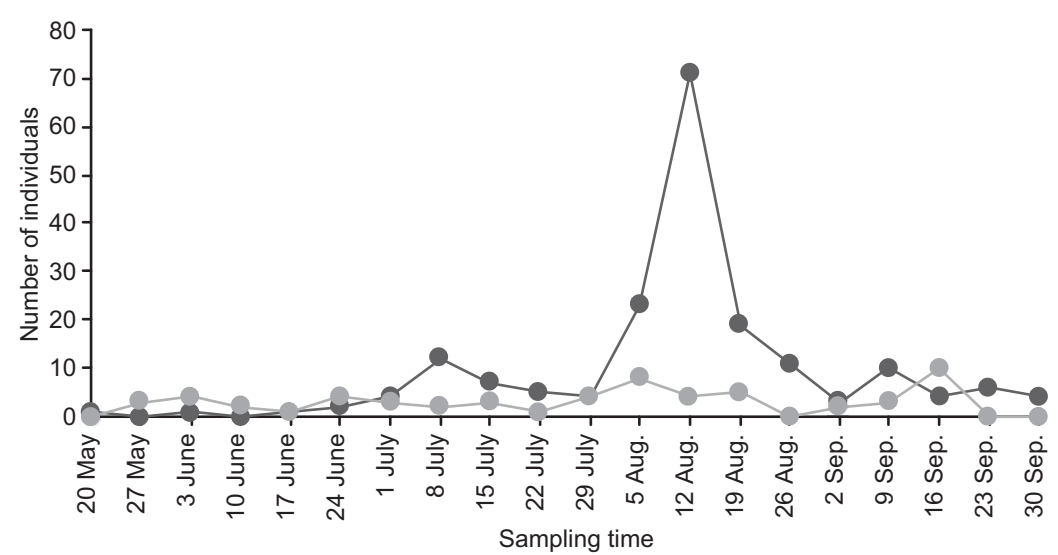

recorded a total of 6 species and 232 individuals ( 2 queens and 230 workers). In the August sampling period, we recorded a total of 5 species and 156 individuals; all being workers.

The average number of wasps per trap was smaller in the gardens than in the woods, but there was no effect of sampling period overall or separately for the two habitats $\left(F_{3,82}=2.83\right.$, $p=0.04$; Table 2 and Fig. 2). Variation in overall abundance was greater in the woods than in the gardens $(F=0.42, \mathrm{df}=21, p=0.025)$.

Of all the individuals, $84 \%$ were Vespula vulgaris. In July, $75 \%$ of the individuals in the gardens and $81 \%$ in the woods were $V$. vulgaris, and in August respective figures were $85 \%$ and $99 \%$. The species was on average more abundant in the woods than in the gardens, but there was no effect of sampling period overall or separately for the two habitats $\left(F_{3,82}=2.35, p=\right.$ 0.08; Table 2 and Fig. 3). Variation in $V$. vulgaris abundance was greater in the woods than in the gardens $(F=0.33, \mathrm{df}=21, p=0.007)$. The overall trap occupancy rates were $95 \%$ and $100 \%$ in the gardens and woods, respectively.

\section{Discussion}

Social wasps were common in the urban gardens and nearby urban woods. This corroborates previous studies in that urban areas provide favourable environment in terms of nesting sites, food and microclimate (Christie \& Hochuli 2009, Nadolski 2013, Sorvari 2018). There was considerable variation in abundance among study locations, which is natural since social wasps live in colonies; thus, traps that are near nests attract more individuals. The fact that variation in abundance was greater in the woods may indicate a lack of suitable nest sites or their lower

Table 1. The numbers of recorded Vespula and Dolichovespula wasps in gardens and woods in the two sampling periods.

\begin{tabular}{|c|c|c|c|c|c|c|}
\hline & \multicolumn{2}{|c|}{ July } & \multicolumn{2}{|c|}{ August } & \multicolumn{2}{|c|}{ Total } \\
\hline & Gardens & Woods & Gardens & Woods & Gardens & Woods \\
\hline V. vulgaris & 76 & 106 & 52 & 90 & 128 & 196 \\
\hline D. media & 10 & 12 & 5 & 4 & 15 & 16 \\
\hline D. saxonica & 11 & 6 & 4 & 0 & 15 & 6 \\
\hline D. norwegica & 2 & 7 & 0 & 0 & 2 & 7 \\
\hline V. germanica & 1 & 0 & 0 & 0 & 1 & 0 \\
\hline D. pacifica & 1 & 0 & 0 & 0 & 1 & 0 \\
\hline D. sylvestris & 0 & 0 & 0 & 1 & 0 & 1 \\
\hline Total & 101 & 131 & 61 & 95 & 162 & 226 \\
\hline
\end{tabular}




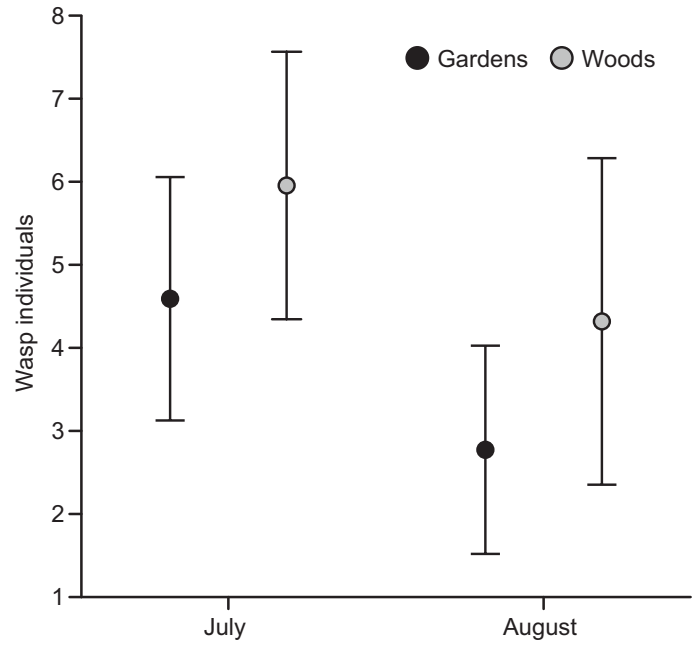

Fig. 2. Mean numbers $( \pm 95 \% \mathrm{Cl})$ of social wasp individuals per trap in gardens and woods in the July and August sampling periods.

density in some woods, whereas lower variation in the gardens may indicate many suitable nest sites, which also allow the nests to grow larger (Nadolski 2012; but see below).

Urban woods can increase wasp abundance in adjacent gardens, especially if gardens attract foragers by providing nectar and other carbohydrate sources, as well as food waste as protein sources; of course, the opposite is also true if certain woods have abundant food sources. Social wasps also orient themselves towards locations where other wasps are foraging, using both visual and olfactory cues (Reid et al. 1995). Wasps learn the exact location of the food source and cannot immediately locate a new food source, even though the food has been moved only about $50 \mathrm{~cm}$ (Lozada \& D'Adamo 2011). Such conspecific attraction and learning

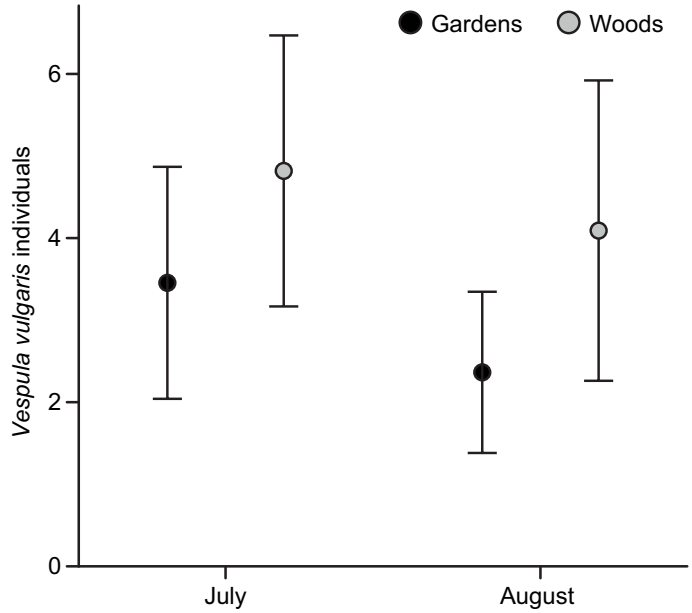

Fig. 3. Mean numbers $( \pm 95 \% \mathrm{Cl})$ of Vespula vulgaris individuals per trap in gardens and woods in the July and August sampling periods.

can contribute to grouping of workers near food resources and baits (Reid et al. 1995). However, it is likely that the overall spill-over effect from woods to gardens is minor as compared with the population size of the urban-dwelling wasps themselves.

The overall wasp abundance, and the abundance of the numerically-dominant Vespula vulgaris, were higher in the woods than in the gardens. Our results support previous studies (Dvorak 2007, Sorvari 2018) in that V. vulgaris is more abundant outside urban areas, although the difference was rather small. Woods may provide more or better nest locations than gardens, because $V$. vulgaris generally nests underground; however, it can also nests in attics, hollow trees and bird nest-boxes. Unfortunately, it is difficult to quantify the availability and quality of nest sites in different types of environments, and

Table 2. Parameter estimates and their significance based on the generalized linear mixed models for all social wasps and Vespula vulgaris.

\begin{tabular}{|c|c|c|c|c|c|c|c|c|}
\hline \multirow[t]{2}{*}{ Term } & \multicolumn{4}{|c|}{ All wasps } & \multicolumn{4}{|c|}{ Vespula vulgaris } \\
\hline & Coeff. & SE & $t$ & $p$ & Coeff. & SE & $t$ & $p$ \\
\hline Intercept & 1.66 & 0.12 & 0.00 & 0.00 & 1.53 & 0.12 & 0.00 & 0.00 \\
\hline Sampling period & -0.15 & 0.12 & -1.26 & 0.21 & -0.07 & 0.12 & -0.58 & 0.56 \\
\hline Habitat (garden)* & -0.39 & 0.19 & -2.09 & 0.04 & -0.48 & 0.20 & -2.41 & 0.02 \\
\hline Sampling period (garden)* & -0.10 & 0.19 & -0.56 & 0.58 & -0.12 & 0.20 & -0.59 & 0.56 \\
\hline
\end{tabular}

\footnotetext{
* These coefficients are contrasted with respective variables in the woods, which were set to 0.
} 
hence to fully understand the factors causing the difference in abundance. Because $V$. vulgaris was overwhelmingly abundant, most of the variation in overall wasp abundance was due to this species. Similar to the overall abundance, also the variation in the abundance of $V$. vulgaris was higher in woods than in gardens, probably for the same reasons. It is important to note that abundance of social wasps vary strongly from year to year (Akre \& Reed 1981, Sorvari 2013, Lester et al. 2017, Badejo et al. 2018), the peaks occurring in even years in many areas of Europe (Pawlikowski \& Pawlikowski 2006, Sorvari 2013, 2018). Our study was conducted during the odd year 2019, so presumably social wasp populations were in their lows. This is supported by reports of very high abundances of social wasps in 2018, which was also noted by Finnish media.

Contrary to our hypotheses, neither the overall wasp abundance nor the abundance of $V$. vulgaris differed between July and August, although the abundance in July was slightly higher. This is somewhat surprising. Although both study periods were a few Celsius degrees warmer than the long-term average, the summer 2019 was not exceptionally warm (see www. ilmatieteenlaitos.fi). Warm weather in late spring and early summer might have advanced colony development and resulted in the observed July peak. However, the July sampling period was about $5{ }^{\circ} \mathrm{C}$ warmer than that of August, and there was no rainfall. This difference in weather is likely to contribute to higher wasp numbers in July. Our monitoring data also show that at some locations in the Jyväskylä city region, the peak abundance, especially that of $V$. vulgaris, was in August. Thus, there seems to be a great deal of local variation in abundance of conspecific populations.

In Finland, there are 12 species of social wasps (Pekkarinen \& Huldén 1995), of which seven were found in our study. All the social parasite species were missing, mainly because they are naturally very sparse, but could also be, that they are not attracted to beer. Our results corroborate previous studies in that Vespula species are more attracted to beer than Dolichovespula species, so the differences in the numbers of trapped individuals unlikely reflect the true abundance differences (see Sorvari 2013, 2018); indeed,
Dolichovespula species are common in urban areas, including Jyväskylä (authors' pers. obs.). Also Vespa crabro is attracted to beer (authors' unpubl. data), but the species does not occur in central Finland. We also recorded Vespula germanica for the first time from the province of central Finland. Vespula germanica is a species, whose distribution is expanding northwards in response to the ongoing climate change. Although it occurred in the Alland islands for decades, it was a rare visitor in the mainland southern Finland and the first potential breeding colony was reported in 2006 (Eeva et al. 2006). In the turn of the decade 2000 to 2010, $\mathrm{V}$. germanica was locally more abundant in urban areas in southern Finland than $V$. vulgaris (Sorvari 2013, 2018).

Urbanization is one of the rapidly growing global anthropogenic pressures on natural biota, but it can also provide resources and environments for a variety of species. Changes in biotic communities can also change encounters and coexistence dynamics between humans and social wasps. Thus, social wasp dynamics and ecology in urban areas deserve further studies.

\section{Acknowledgements}

We thank Juraj Švajda, Anna Lähde and Salla Pitkänen for their help in the field. The study was funded by the Kone Foundation (grant no. 201800577).

\section{References}

Akre, R. D. \& Reed, H. C. 1981: Population cycles of yellowjackets in the Pacific Northeast (Hymenoptera: Vespinae). - Environmental Entomology 10: 267-274.

Archer, M. E. 2012: Vespine wasps of the world. - Siri Scientific Press, Manchester.

Badejo, O., Skaldina, O. \& Sorvari, J. 2018: Spatial and temporal variation in thermal melanism in the aposematic Common Wasp (Vespula vulgaris) in northern Europe. - Annales Zoologici Fennici 55: 67-78.

Christie, F. J. \& Hochuli, D. F. 2009: Responses of wasp communities to urbanization: effects on community resilience and species diversity. - Journal of Insect Conservation 13: 213-221.

Douwes, P., Abenius, J., Cederberg, B., Wahlstedt, U., Hall, K., Starkenberg, M., Reisborg, C. \& Östman, T. 2012: Nationalnyckeln till Sveriges flora och fauna. Steklar: Myror-getingar. Hymenoptera: Formicidae-Vespidae. 
- ArtDataBanken, SLU, Uppsala.

Dvorak, L. 2007: Social wasps (Hymenoptera: Vespidae) trapped with beer in European forest ecosystems. Acta Musei Moraviae, Scientiae biologicae (Brno) 92: 181-204.

Eeva, T., Sorvari, J. \& Rinne, V. 2006: A likely German wasp (Vespula germanica) breeding colony in continental Finland. - Sahlbergia 11: 53-54.

Grimmond, S. 2007: Urbanization and global environmental change: local effects of urban warming. - The Geographical Journal 173: 83-88.

Jeanne, R. L. \& Bouwma, A. M. 2002: Scaling in nests of a social wasp: a property of the social group. - The Biological Bulletin 202: 289-295.

Kruess, A. \& Tscharntke, T. 1994: Habitat fragmentation, species loss, and biological control. - Science 264: 1581-1584.

Lester, P. J., Haywood, J., Archer, M. E. \& Shortall, C. R. 2017: The long-term population dynamics of common wasps in their native and invaded range. - Journal of Animal Ecology 86: 337-347.

Lozada, M. \& D’Adamo, P. 2011: Past experience: a help or a hindrance to Vespula germanica foragers? - Journal of Insect Behavior 24: 159-166.

McDonald, R. I., Marcotullio, P. J. \& Güneralp, B. 2013: Urbanization and global trends in biodiversity and ecosystem services. - In: Elmqvist, Th., Fragkias, M., Goodness, J., Güneralp, B., Marcotullio, P. J., McDonald, R. I., Parnell, S., Schewenius, M., Sendstad, M., Seto, K. C. \& Wilkinson, C. (eds.), Urbanization, biodiversity and ecosystem services: challenges and opportunities: a global assessment: 31-52. SpringerOpen, Dordrecht.

McKinney, M. L. 2002: Urbanization, biodiversity, and conservation: rhe impacts of urbanization on native species are poorly studied, but educating a highly urbanized human population about these impacts can greatly improve species conservation in all ecosystems. - BioScience 52: 883-890.

Nadolski, J. 2012: Structure of nests and colony sizes of the European hornet (Vespa crabro) and Saxon wasp (Dolichovespula saxonica) (Hymenoptera: Vespinae) in urban conditions. - Sociobiology 59: 1075-1120.

Nadolski, J. 2013: Factors restricting the abundance of wasp colonies of the European hornet Vespa crabro and the Saxon wasp Dolichovespula saxonica (Hymenoptera: Vespidae) in an urban area in Poland. - Entomologica Fennica 24: 204-215.

Niemelä, J. 1999: Ecology and urban planning. — Biodiversity and Conservation 8: 119-131.

Pawlikowski, T. \& Pawlikowski, K. 2006: Long-term dynamics of structure changes of the social wasp community (Hymenoptera: Vespinae) in agricultural landscape of the Kujawy Region. - Ecological Questions 7: 21-28.

Pekkarinen, A. \& Huldén, L. 1995: Distribution and phenology of the Vespinae and Polistinae species in eastern Fennoscandia (Hymenoptera: Vespidae). — Sahlbergia 2: 99-111.

Raveret Richter, M. R. 2000: Social wasp (Hymenoptera: Vespidae) foraging behavior. - Annual Review of Entomology 45: 121-150.

Reid, B. L., MacDonald, J. F. \& Ross, D. R. 1995: Foraging and spatial dispersion in protein-scavenging workers of Vespula germanica and $V$. maculifrons (Hymenoptera: Vespidae). - Journal of Insect Behavior 8: 315-330.

Sorvari, J. 2013: Social wasp (Hymenoptera: Vespidae) beer trapping in Finland 2008-2012: a German surprise. Entomologica Fennica 24: 156-164.

Sorvari, J. 2018: Habitat preferences and spring temperaturerelated abundance of German wasp Vespula germanica in its northern range. - Insect Conservation and Diversity 11: 363-369.

Sumner, S., Law, G. \& Cini, A. 2018: Why we love bees and hate wasps. - Ecological Entomology 43: 836-845. 